\title{
Adult-Onset Leukoencephalopathy with Axonal Spheroids and Pigmented Glia
}

National Cancer Institute

\section{Source}

National Cancer Institute. Adult-Onset Leukoencephalopathy with Axonal Spheroids and

Pigmented Glia. NCI Thesaurus. Code C153289.

A rapidly progressive neurodegenerative disorder, caused by mutations in the colonystimulating factor 1 receptor (CSF1R) gene, that presents in adulthood with a variety of neuropsychiatric and motor disturbances. Hallmark features include diffuse myelin loss and axonal destruction, neuroaxonal spheroids, and pigmented macrophages and other glia. 